\title{
PEMBUATAN PERMEN SUSU RASA JAHE DI KELOMPOK WANITA TANI KECAMATAN BATU KOTA BATU
}

\section{The Making of Ginger Flavored Milk Candy on Women's Farmers Group in Batu Subdistrict of Batu City}

\author{
Finda Swastika Emas' ${ }^{1}$, Luki Amar Hendrawati², Ach. Syamsuddin ${ }^{2}$ \\ ${ }^{1}$ Alumni STPP Malang \\ 2Program Studi Penyuluhan Peternakan STPP Malang \\ Email: findaemas@gmail.com
}

\begin{abstract}
INTISARI
Pembuatan permen susu rasa jahe dilakukan karena Kelompok Wanita Tani (KWT) di Kecamatan Batu membutuhkan produk dengan memanfaatkan potensi susu dan tanaman jahe yang melimpah. Tujuan penelitian ini adalah mengetahui hasil pembuatan permen susu rasa jahe. Metode penelitian ini adalah Kaji Widya. Permen susu rasa jahe yang dibandingkan adalah permen susu dengan bubuk jahe dan jahe yang digeprek. Alat analisis yang digunakan adalah uji organoleptik dengan aspek yang diukur antara lain warna, rasa, aroma, dan tekstur. Hasil uji organoleptik menunjukkan bahwa permen susu yang menggunakan jahe yang digeprek lebih banyak disukai oleh panelis. Jika KWT hendak membuat permen susu rasa jahe sebagai produk, maka direkomendasikan untuk menggunakan jahe geprek.
\end{abstract}

Kata kunci: Permen Susu Rasa Jahe, Uji Organoleptik, KWT

\begin{abstract}
The making of Ginger Flavored Milk Candy was done because the Women Farmers Group (KWT) in Batu District needs products by utilizing the abundant potency of milk and ginger plants. The population of dairy cows in Batu District in 2017 was 4,475, have milk production of 385,710 liters / year. The production of ginger was 30-40 tons per year in an area of 3-4 hectares. The purpose of this study was to find out the results of making Ginger Flavored Milk Candy. The research method used was Kaji Widya. The ginger flavored milk candy that was compared was milk candy with ginger powder and crushed ginger. The analytical tool used was Organoleptic Test with the measured aspects including color, taste, aroma, and texture. The results of organoleptic tests showed that milk candy that uses ginger which was crushed was morepreferred by panelists. If KWT wants to make ginger milk candy as a product,then it is recommended to use crushed ginger.
\end{abstract}

Keywords: Ginger Flavored Milk Candy, Organoleptic Test, KWT

\section{PENDAHULUAN}

Susu merupakan bahan makanan yang dihasilkan ternak perah baik sapi maupun kambing dengan kandungan nutrisi terlengkap dalam pemenuhan konsep gizi yang dikenal dengan empat sehat lima sempurna. Berbagai macam produk olahan susu sudah banyak dijumpai di berbagai pusat makanan baik yang berasal dari impor maupun produk dalam negeri (Sistanto,
2014). Susu adalah suatu sekresi kelenjar susu dari sapi yang sedang laktasi atau ternak yang sedang laktasi, dan dilakukan pemerahan dengan sempurna, tidak termasuk kolostrum serta tidak ditambah atau dikurangi oleh suatu komponen (Soeparno et al., 2011). Kandungan gizi yang tinggi pada susu menyebabkan susu menjadi media sempurna bagi pertumbuhan bakteri, sehingga susu menjadi cepat rusak yang ditandai dengan rasa asam dan basi (Rofiah, 2014). 
Kecamatan Batu merupakan salah satu daerah di Kota Batu yang mempunyai potensi di bidang peternakan pada komoditas sapi perah. Hal ini didukung dengan letak geografis yang berada di wilayah dataran tinggi (500 sampai $1.600 \mathrm{mdpl}$ ), sehingga dinilai sesuai untuk budidaya ternak sapi perah. Temperatur udara yang tergolong sejuk dengan curah hujan rata-rata 2.000 sampai $3.000 \mathrm{~mm}$ sepanjang tahun. Salah satu sentra penghasil susu segar di Kecamatan Batu berada di Desa Oro-oro Ombo. Desa tersebut juga menghasilkan Jahe Emprit dan Jahe Gajah yang dapat tumbuh dengan baik. Data tahun 2017 menunjukkan bahwa seluas 3 sampai 4 hektar yang mampu menghasilkan sebanyak 30 sampai 40 ton/tahun. Populasi sapi perah di Kota Batu tahun 2016 sebanyak 11.611 ekor (BPS, 2018). Identifikasi Potensi Wilayah (IPW) menunjukkan bahwa kebutuhan dan ketertarikan Kelompok Wanita Tani (KWT) terhadap kegiatan teknologi pengolahan hasil ternak sehingga dapat menghasilkan produk unggulan khas daerah. Peternak pada saat ini belum dapat memanfaatkan susu yang diproduksi secara optimal sehingga membutuhkan diversifikasi produk olahan susu yaitu dengan membuat permen susu.

Permen susu merupakan jenis permen yang dibuat dengan menggunakan berbahan dasar susu dan gula (Andajani, 2015). Permen susu dibuat menggunakan susu yang tidak memerlukan persyaratan mutu tinggi, sehingga cara ini dapat menjadi salah satu alternatif dalam pemanfaatan susu. Keunggulan dari pembuatan permen susu jika ditinjau dari aspek teknis yaitu mudah dilakukan, membutuhkan waktu yang singkat, dan mempunyai nilai ekonomis tinggi.

Adanya variasi penambahan rasa dalam adonan menjadi permen susu rasa jahe diharapkan mampu menjadi trend baru di masyarakat yang menarik konsumen, dengan cara menggabungkan potensi dan komoditas unggulan di Kecamatan Batu berupa susu dan jahe.. Dari uraian di atas maka dibuat permen susu rasa jahe di KWT Kecamatan Batu, Kota Batu, Provinsi Jawa Timur.

\section{MATERI DAN METODE}

Penelitian ini dilaksanakan pada 5 Maret sampai 1 Juni 2018 di Kecamatan Batu, Kota Batu. Metode yang digunakan adalah Kaji Widya. Bahan yang digunakan adalah $1 \mathrm{~L}$ susu segar, $300 \mathrm{~g}$ gula pasir, $50 \mathrm{~g}$ jahe, dan $7 \mathrm{~g}$ agar-agar. Perlakuan penelitian ini adalah permen susu rasa jahe yang berbahan bubuk jahe dan jahe geprek.

Hasil dari pembuatan permen susu rasa jahe selanjutnya dilakukan uji organoleptik yaitu berdasarkan skoring yaitu sangat tidak suka (1) sampai sangat suka (5) dengan panelis yang tidak terlatih dari KWT. Data hasil organoleptik diuji menggunakan uji Paired t-test yaitu uji untuk mengetahui ada tidaknya perbedaan nilai rata-rata dua kelompok data yang berpasangan, sehingga dihasilkan nilai rata-rata (mean) dan Sig. (2tailed) untuk mengetahui nilai signifikansi terhadap produk yang diuji (Steel dan Torrie, 1993).

\section{HASIL DAN PEMBAHASAN}

Hasil Kaji Widya ini yaitu untuk mengetahui tingkat kesukaan warna, rasa, aroma, dan tekstur pada hasil pembuatan permen susu rasa jahe yang berbahan bubuk jahe dan jahe geprek. Berikut ini adalah hasil dari uji organoleptik disajikan pada Tabel 1.

Berdasarkan hasil uji Paired t-test menunjukkan terdapat perbedaan yang signifikan antara permen susu rasa jahe berbahan bubuk jahe dan jahe geprek. Dasar pengambilan keputusan sebagai berikut.

1. Jika nilai Sig. (2-tailed $)<0,01$, maka terdapat perbedaan yang signifikan antara daya suka pada permen susu rasa jahe berbahan bubuk jahe dan jahe geprek.

2. Jika nilai Sig. (2-tailed) $>0,01$, maka tidak terdapat perbedaan yang signifikan antara 
daya suka pada permen susu rasa jahe berbahan bubuk jahe dan jahe geprek.

Tingkat kesukaan dapat diketahui melalui uji organoleptik. Uji organoleptik bertujuan mengetahui tingkat kesukaan terhadap permen susu rasa jahe berbahan bubuk jahe dan jahe geprek meliputi warna, rasa, aroma, dan tekstur.

Tabel 1. Hasil uji organoleptik permen susu rasa jahe

\begin{tabular}{llcc}
\hline \multicolumn{1}{c}{ Perlakuan } & Perlakuan & Mean & Sig. (2-tailed) \\
\hline \multirow{2}{*}{ Warna } & Bubuk jahe & 2.9467 & .002 \\
& Jahe geprek & 4.1100 & .010 \\
\multirow{2}{*}{ Rasa } & Bubuk jahe & 3.3100 & .086 \\
\multirow{2}{*}{ Aroma } & Jahe geprek & 3.9567 & .086 \\
& Bubuk jahe & 3.2533 & .010 \\
\multirow{2}{*}{ Tekstur } & Jahe geprek & 3.9433 & .034 \\
& Bubuk jahe & 3.0567 & .016 \\
& Jahe geprek & 3.7867 & .018 \\
\hline
\end{tabular}

Berdasarkan hasil uji organoleptik yang dilakukan pada permen susu rasa jahe berbahan bubuk jahe dan jahe geprek menunjukkan tingkat kesukaan yang lebih tinggi yaitu pada penggunaan jahe geprek.

Warna permen susu berbahan dasar jahe geprek menghasilkan nilai kesukaan lebih tinggi daripada yang berbahan dasar bubuk jahe. Hal ini dibuktikan dengan nilai rata-rata hasil uji organoleptik panelis terhadap warna yang berbeda secara nyata yaitu dengan nilai 4,1 dibandingkan 2,9. Berdasarkan catatan dari panelis yang menyatakan bahwa warna yang dihasilkan oleh permen susu rasa jahe berbahan bubuk jahe yaitu kurang menarik. Jika dibandingkan dengan Permen Susu Rasa Jahe berbahan jahe yang digeprek bahwa menurut panelis memiliki warna yang lebih menarik.

Sedangkan pada rasa yang dihasilkan pada hasil pembuatan Permen Susu Rasa Jahe berbahan bubuk jahe jika dibandingkan dengan jahe yang digeprek ini hampir sama. Hal ini dibuktikan dengan nilai rata-rata hasil ujiorganoleptik panelis terhadap rasa yang tidak berbeda jauh yaitu dengan nilai 3,3

dibandingkan 3,9. Berdasarkan catatan dari panelis yang menyatakan bahwa rasa yang dihasilkan oleh permen susu rasa jahe berbahan bubuk jahe yaitu lebih dominan rasa susu dan rasa jahe kurang terasa. Sedangkan pada permen susu rasa jahe berbahan jahe yang digeprek bahwa menurut panelis memiliki rasa yang tepat dan seimbang antara susu dan jahe yang khas. Hal ini dikarenakan jahe yang digunakan merupakan jahe asli segar yang digeprek sehingga dapat menghasilkan cita rasa yang khas.

Pada aroma yang dihasilkan pada hasil pembuatan permen susu rasa jahe berbahan bubuk jahe jika dibandingkan dengan jahe yang digeprek ini hampir sama. Hal ini dibuktikan dengan nilai rata-rata hasil uji organoleptik panelis terhadap aroma yang tidak berbeda jauh yaitu dengan nilai 3,2 dibandingkan 3,9. Berdasarkan catatan dari panelis yang menyatakan bahwa aroma yang dihasilkan oleh Permen Susu Rasa Jahe berbahan bubuk jahe yaitu lebih dominan aroma susu dan aroma jahe kurang. Sedangkan pada Permen Susu Rasa Jahe berbahan jahe yang digeprek bahwa menurut panelis memiliki aroma susu yang khas dengan jahe.

Pada tekstur yang dihasilkan pada hasil pembuatan permen susu rasa jahe berbahan bubuk jahe jika dibandingkan dengan jahe yang digeprek ini hampir sama. Hal ini dibuktikan dengan nilai rata-rata hasil uji organoleptik panelis terhadap aroma yang tidak berbeda jauh yaitu dengan nilai 3,0 dibandingkan 3,7. Berdasarkan catatan dari panelis yang menyatakan bahwa tekstur yang dihasilkan oleh permen susu rasa jahe 
berbahan bubuk jahe yaitu lebih kasar dan kurang menarik. Jika dibandingkan dengan permen susu rasa jahe berbahan jahe yang digeprek bahwa menurut panelis memiliki tekstur yang lebih bagus dan lembut serta padat. Maka penambahan jahe yang baik adalah pada penambahan jahe segar dibandingkan dengan jahe bubuk. Hal ini di karenakan bahwa jahe segar mempunyai sifat aroma yang menyegat dan segar. Penambahan jahe tersebut bertujuan untuk untuk memberikan aroma pada permen susu karena jahe mengandung minyak atsiri (ginger oil) 0,25 sampai $3,3 \%$ pembawa aroma dan rasa sedikit pedas dari jahe (aroma khas jahe) dan minyak ini terdiri atas beberapa jenis minyak terpenting yaitu zingiberene, curcumene, dan philandren. Adapun kandungan lainnya yang terdapat pada jahe yaitu protein $9 \%$, zat tepung 50\% lebih, vitamin khususnya niacin dan vitamin A, juga beberapa jenis zat mineral, damar, dan sebagainya (Rismunandar, 1996). Susu akan berkurang bau khas susunya setelah ditambahkan jahe segar dibandingkan jahe bubuk/instan. Hal ini sesuai dengan pendapat Koswara (1995) bahwa jahe yang masih belum diolah atau segar mengandung zat-zat yang masih murni, aroma khas jahe dan kandungan oleoresinnya dapat menghasilkan warna yang baik pada produk yang di hasilkan.

\section{KESIMPULAN DAN SARAN}

\section{Kesimpulan}

Hasil uji organoleptik terhadap permen susu rasa jahe yaitu nilai rata-rata kesukaan panelis pada daya suka warna permen susu rasa jahe menggunakan jahe yang digeprek lebih tinggi jika dibandingkan dengan permen susu rasa jahe menggunakan jahe bubuk.

\section{DAFTAR PUSTAKA}

Andajani, P.T. 2015. Buku Pintar Peternakan Jilid II. Media Nusa Creative. Malang. Badan Pusat Statistik. 2018. Populasi Sapi
Perah Menurut Kabupaten/Kota di Jawa Timur Tahun 2009-2016 (Ekor). https://lamongankab.bps.go.id/staticta ble/2018/02/23/1163/populasi-sapiperah-menurut-kabupaten-kota-dijawa-timur-tahun-2009-2016-ekor.html. Diakses tanggal 11 November 2018.

Rismunandar. 1996. Rempah-Rempah: Komoditi Ekspor Indonesia. Sinar Baru Algensindo. Bandung.

Rofiah, A. 2014. Kajian Dosis Sukrosa dan Sirup Glukosa Terhadap Kualitas Permen Karamel Susu. Jurnal Nabatia. 11(1): 55-65.

Koswara, S. 1995. Jahe dan Hasil Olahannya. Pustaka Sinar Harapan. Jakarta.

Steel, R.G.D. dan J.H. Torrie. 1993. Prinsip dan Prosedur Statistika (diterjemahkan dari: Principles and Procedures of Statistic, penerjemah: B. Sumantri). PT Gramedia. Jakarta.

Sistanto. 2014. Sifat Fisikokimia dan Organoleptik Permen Susu (Karamel) Rasa Jahe (Zingiber officinale Roscoe) dan Temulawak (Curcuma xanthorriza Roxb). Jurnal Sains Peternakan Indonesia.

Soeparno, R.A. Rihastuti, Indratiningsih, S. Triatmojo. 2011. Dasar Teknologi Hasil Ternak. UGM Press. Yogyakarta. 